Acta Theriologica 38 (2): 151 - 159, 1993.

PL ISSN $0001-7051$

\title{
Movements of European brown bears in Croatia
}

\author{
Djuro HUBER and Hans U. ROTH
}

\begin{abstract}
Huber D. and Roth H. U. 1993. Movements of European brown bears in Croatia. Acta theriol. 38: $151-159$.

Twenty six European brown bears Ursus arctos Linnaeus, 1758 were captured, radio-collared, and tracked in and around Plitvice Lakes and Risnjak National Parks from 01 November 1981 to 25 July 1991. The largest male and female ranges were $224 \mathrm{~km}^{2}$ and $147 \mathrm{~km}^{2}$, respectively. Mean annual ranges were $128 \mathrm{~km}^{2}$ and $58 \mathrm{~km}^{2}$ for males and females, respectively. Male ranges were 2 to 5 times larger than female ranges. The median straight-line distance between consecutive day locations was 1.5 $\mathrm{km}$ for all bears and the maximum distance was $8.5 \mathrm{~km}$. Distances traveled daily by males and females were similar, but movements of females were restricted to smaller areas. Winter ranges were significantly smaller than ranges during other seasons. Marked bears spent $52 \%$ of their time outside the Plitvice Lakes and Risnjak National Parks.
\end{abstract}

Biology Department, Veterinary Faculty, Heinzelova 55, 41000 Zagreb, Republic of Croatia (DH); Neumatt 15, 3323 Bariswil, Switzerland (HUR)

Key words: Ursus arctos, movements, radio-telemetry, Croatia

\section{Introduction}

European brown bears Ursus arctos Linnaeus, 1758, unlike North American grizzly bears, have developed elusive behavior over the last millennia parallel with increasing human numbers and technology. As a result, the species inhabits relatively densely populated areas (up to $70 \mathrm{humans} / \mathrm{km}^{2}$, Roth 1978). In spite of these adaptations, the range of brown bears, once extending over most of Europe, is now fragmented into approximately 16 isolated populations (Servheen 1990). The Dinara mountains hold one of the largest of these populations, ranging over some $60,000 \mathrm{~km}^{2}$, mostly in Slovenia, Croatia, Bosnia and Hercegovina, Montenegro and Macedonia (Huber and Morić 1989), and smaller areas in Albania and northern Greece (Servheen 1990).

The results reported here are part of a continuing study on a wide range of aspects of the biology of free-ranging brown bears in Croatia. Quantitative data is presented which should allow managers to make decisions based on existing movement patterns. Preliminary data on bears P1 and P2 were reported earlier (Huber and Roth 1986). 


\section{Study areas}

We studied bears in the National Parks of Plitvice Lakes (PLNP) and Risnjak (RNP) and the lands surrounding them (Fig. 1). Both Parks are part of continuous bear habitat along the Dinara Mountain range and occur in the center of the most important bear habitat in the Republic of Croatia. Approximately 400 brown bears are believed to inhabit Croatia (Huber and Moric 1989).

PLNP $\left(192 \mathrm{~km}^{2}\right.$ ), located $60 \mathrm{~km}$ from the sea coast, was established in 1949. Elevations range from 417 to $1,280 \mathrm{~m}$. Yearly precipitation averages $1,360 \mathrm{~mm}$, and average monthly temperatures range from -2.6 C in January to $17.0 \mathrm{C}$ in July. Annual snow cover lasts 60 to 108 days (Makjanic 1971/72).

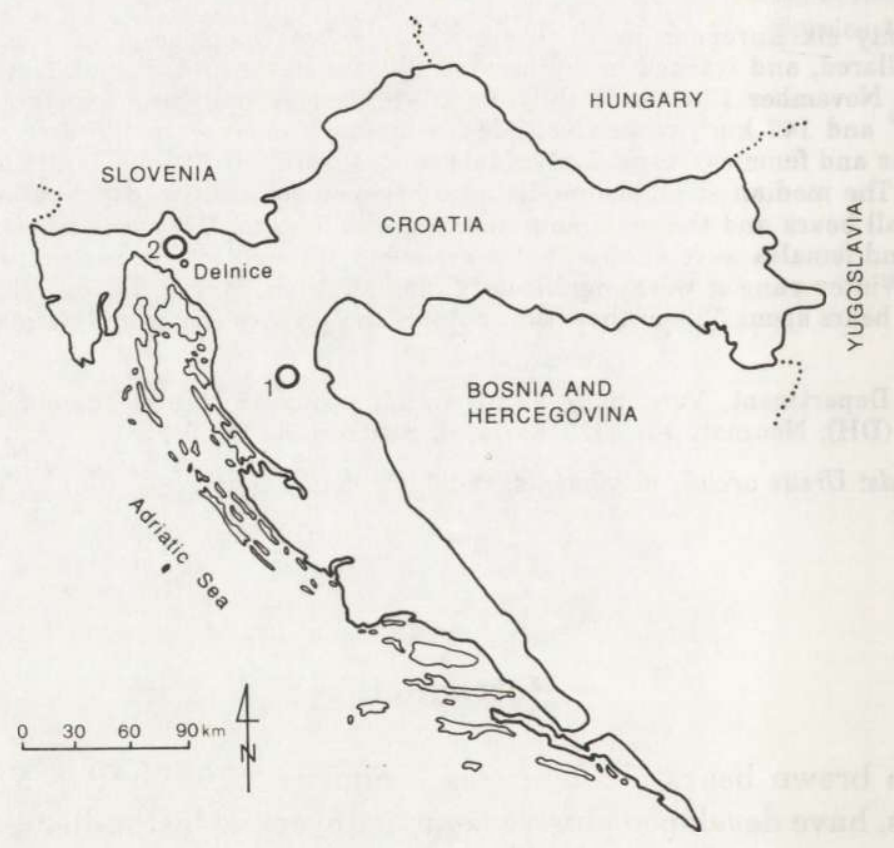

Fig. 1. Location of Plitvice Lakes (1) and Risnjak (2) National Parks in Croatia.

RNP $\left(30 \mathrm{~km}^{2}\right)$, located $100 \mathrm{~km}$ north-west of PLNP, and $15 \mathrm{~km}$ from the sea coast, was established in 1953. Elevations range from 726 to $1,528 \mathrm{~m}$. Yearly precipitation on the top of Risnjak Mountain averages $3,579 \mathrm{~mm}$ with average monthly temperatures ranging from $-3.6 \mathrm{C}$ in February to $12.6 \mathrm{C}$ in July. In the nearby town of Delnice at $698 \mathrm{~m}$ above sea level the average yearly precipitation is $2,486 \mathrm{~mm}$ and the temperature ranges from $-1.2 \mathrm{C}$ in January to $14.2 \mathrm{C}$ in July. Annual snow cover lasts on the average 165 days (Bertovic and Martinovic 1981).

Forests cover about $75 \%$ of PLNP and over $90 \%$ of RNP. This are dominated by a mixture of beech Fagus sylvatica, fir Abies alba, spruce Picea abies, and other tree species varying in composition with elevation and exposure. The topography has typical karst features with various depressions without surface drainage. Limestone bedrock is covered with shallow soils; the mountain peaks are formed by bare rocks. 
In addition to brown bears, the large mammal fauna of both parks contain gray wolves Canis lupus, red foxes Vulpes vulpes, lynx Lynx lynx, European wild cats Felis silvestris, roe deer Capreolus capreolus, red deer Cervus elaphus, and wild boars Sus scrofa.

The major tourist attraction in PLNP is a series of 16 lakes connected by waterfalls that cover approximately $1 \%$ of the park. These lakes were visited by up to 700,000 people each year but few people used parts of PLNP > $1 \mathrm{~km}$ from the lakes. Density of human residents in and around PLNP averages $13 / \mathrm{km}^{2}$.

RNP receives few tourists and only a few hundred backpackers climb Risnjak Mountain annually. There is no resident human population within RNP; 27 inhabitants $/ \mathrm{km}^{2}$ inhabit adjacent areas outside RNP.

\section{Methods}

Bears were captured with spring activated foot snares baited with slaughterhouse refuse or animal carcasses, and immobilized with ketamine hydrochloride and xylazine hydrochloride administered by dart-gun or blow pipe. Bears were fitted with transmitter-collars with break-away connectors. A rudimentary first premolar tooth was extracted for age estimation (Stoneberg and Jonkel 1966).

Locations of radio-marked bears were determined by ground triangulation and aerial tracking from a fix-winged plane. Range sizes were calculated by the convex polygon method (Mohr 1947).

Our data indicated that individual range sizes continued to increase beyond the 50 locations considered sufficient to define home range size (Bekoff and Mech 1984). Therefore we used the term "range" as a measure of mobility only. Movements of individual bears were analyzed by season and year. Seasons were spring (March - May), summer (June - August), fall (September - November), and winter (December - February). Straight-line distances were measured between two locations made on two consecutive days. The median of these distances was used as a measure of central tendency because the frequency distribution was strongly and positively skewed (Roth 1983).

Chi-square- and $t$-tests were used for statistical comparisons of results; $p<0.05$ was considered as statistically significant difference.

\section{Results}

A total of 4,256 trap nights yielded 34 captures including 3 recaptures and 5 captures of bears not radio-tagged. Twenty-six different bears (14 in Plitvice Lakes and 12 in Risnjak) were radio-collared and tracked (Table 1). Only 6 of 26 monitored animals were females $\left(p<0.01, \chi^{2}=7.54, \mathrm{df}=1\right), 1$ of 14 in Plitvice Lakes and 5 of 12 in Risnjak. Fifteen bears were adults ( $\geq 4$ years) and 11 subadults, with an overall mean age of 4.7 years (range $1-13, \mathrm{SD}=3.1$ ) at the time of capture. No significant age difference between sexes was found $(p<0.5$, $t$-test). On 5 occasions we tracked family groups of bears. P1 and P8 were yearlings accompanied by their mothers and siblings. R5 gave birth to at least 1 , and R6 to 3 cubs during the tracking period. R9 was accompanied by 2 yearlings when captured. R12 was a 6 month old orphaned cub when marked and he survived alone a: least 15 months. Mean mass of adult females was $103 \mathrm{~kg}(n=3, \mathrm{SD}=$ $44)$ and $153 \mathrm{~kg}(n=12, \mathrm{SD}=49)$ for adult males.

Radio-marked bears were located 517 times, including 487 times on different days. Females were tracked an average of 712 days compared to 250 days for 
Table 1. The elementary data of brown bears radio-marked in Croatia. ${ }^{*} \mathrm{P}=$ Plitvice area; $\mathrm{R}=\mathrm{Risnjak}$ area, ${ }^{* *}$ Only one location per day listed.

\begin{tabular}{lcrrrrrrr}
\hline $\begin{array}{l}\text { Bear } \\
\text { number* }\end{array}$ & Sex & $\begin{array}{c}\text { Age } \\
\text { (yrs) } \\
\text { (at capture) }\end{array}$ & $\begin{array}{c}\text { Mass } \\
\text { (kg) }\end{array}$ & $\begin{array}{c}\text { Date } \\
\text { of } \\
\text { capture }\end{array}$ & $\begin{array}{c}\text { Monitored } \\
\text { period } \\
\text { (days) }\end{array}$ & $\begin{array}{c}\text { Number } \\
\text { of } \\
\text { locations** }\end{array}$ & $\begin{array}{c}\text { Minimum } \\
\text { polygon } \\
\left(\mathrm{km}^{2} \text { ) }\right.\end{array}$ & $\begin{array}{c}\text { Longest } \\
\text { axis of } \\
\text { range (km) }\end{array}$ \\
\hline P1 & F & 1 & 39 & 01 Nov 81 & 663 & 130 & 95.7 & 14.3 \\
P2 & M & 5 & 135 & 17 Jun 82 & 1330 & 86 & 223.7 & 19.4 \\
P3 & M & 6 & 165 & 15 May 83 & 128 & 17 & 97.3 & 24.4 \\
P4 & M & 3 & 101 & 17 May 83 & 121 & 6 & 57.7 & 15.1 \\
P5 & M & 7 & 222 & 09 Sep 84 & 31 & 3 & 0.6 & 2.1 \\
P6 & M & 5 & 187 & 22 Apr 85 & 326 & 27 & 109.7 & 16.9 \\
P7 & M & 2 & 55 & 23 Apr 85 & 38 & 6 & 17.7 & 12.2 \\
P8 & M & 1 & 20 & 28 Apr 85 & 133 & 5 & 3.7 & 5.4 \\
P9 & M & 5 & 119 & 03 May 86 & 13 & 2 & 0.0 & 8.5 \\
P10 & M & 4 & 104 & 08 May 86 & 206 & 9 & 73.8 & 22.8 \\
P11 & M & 5 & 86 & 14 May 86 & 107 & 4 & 23.7 & 14.1 \\
P12 & M & 5 & 156 & 09 May 87 & 1 & 1 & 0.0 & 0.0 \\
P13 & M & 5 & 111 & 27 Apr 88 & 352 & 5 & 30.3 & 8.8 \\
P14 & M & 3 & 59 & 27 Apr 88 & 314 & 2 & 0.0 & 7.8 \\
R1 & M & 3 & 81 & 27 Apr 86 & 291 & 7 & 150.3 & 30.2 \\
R2 & F & 5 & 72 & 21 May 86 & 652 & 35 & 77.6 & 14.2 \\
R3 & M & 12 & 193 & 26 May 86 & 222 & 13 & 40.2 & 13.7 \\
R4 & M & 3 & 97 & 25 May 87 & 349 & 16 & 134.9 & 21.8 \\
R5 & F & 3 & 62 & 25 May 87 & 840 & 38 & 146.9 & 16.9 \\
R6 & F & 10 & 84 & 12 Jun 87 & 639 & 6 & 49.2 & 15.1 \\
R7 & M & 2 & 52 & 22 Jun 87 & 283 & 18 & 63.9 & 11.8 \\
R8 & M & 4 & 120 & 28 Oct 89 & 83 & 2 & 0.0 & 3.0 \\
R9 & F & 13 & 153 & 29 Oct 89 & 914 & 17 & 28.1 & 10.0 \\
R10 & M & 8 & 237 & 07 Nov 89 & 228 & 6 & 27.2 & 14.6 \\
R11 & F & 2 & 43 & 30 Jun 90 & 561 & 10 & 7.9 & 4.3 \\
R12 & M & 1 & 12 & 18 Jul 89 & 451 & 16 & 37.6 & 14.9 \\
\hline & & & & & & & & \\
\end{tabular}

males ( $p<0.01, t=2.82, \mathrm{df}=24$ ). All 6 females were tracked over 1 year (range: $561-914$ days), while only 2 of 23 collars placed on males (including 3 recaptures) lasted $1>$ year; 14 collars were removed by the bear, 5 transmitters ceased functioning and 2 bears were killed. Each female and male were located an average of 39 (range: $6-130$ ) and 13 (range: $1-86$ ) times, respectively. Only $58 \%$ of 434 day searches for males were successful, compared to $71 \%$ of 333 day searches for females $\left(p<0.01, \chi^{2}=13.3, \mathrm{df}=1\right)$.

Only 3 of 14 radio-tracked bears in the Plitvice Lakes area did not leave the National Park (Fig. 2). However, those 3 bears (P5, P8 and P12) were located only few times (Table 1). The other 11 bears were located up to $11.3 \mathrm{~km}$ (mean maximum distance $=4.7 \mathrm{~km}$ ) beyond PLNP boundaries. Nearly one-half (145 of 303) of the locations in this area were outside the PLNP boundaries. The total area known to be used by all 14 bears was $736 \mathrm{~km}^{2}$. Only 2 of 7 bears tracked 


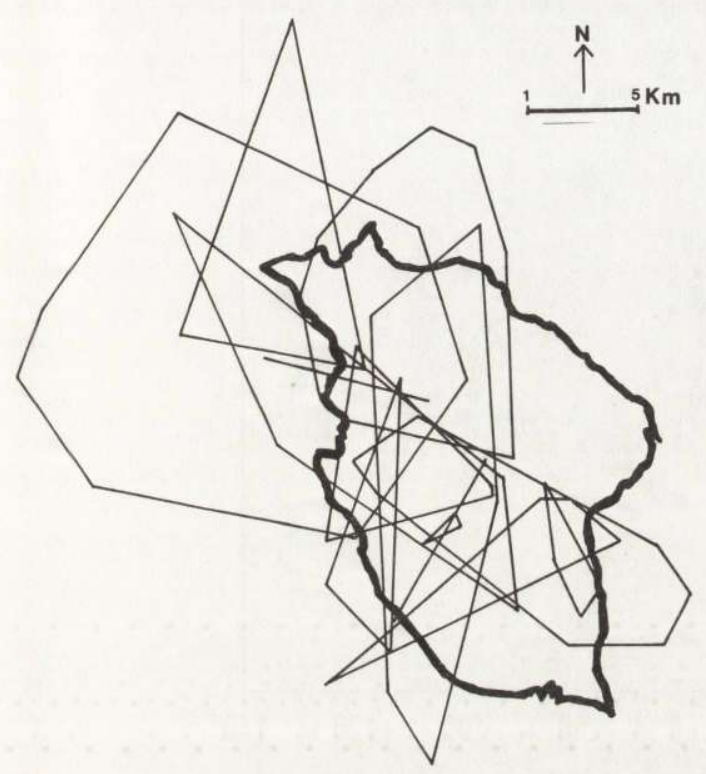

Fig. 2. Ranges of 13 brown bears marked within Plitvice Lakes National Park in relation to the park boundaries.

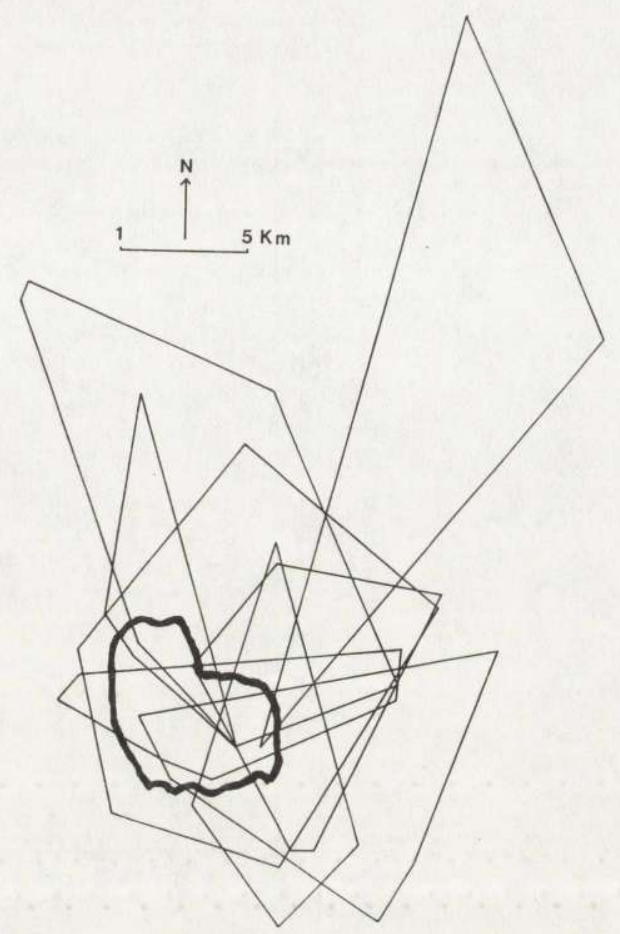

Fig. 3. Ranges of 8 brown bears marked within Risnjak National Park in relation to the park boundaries.

over winter denned within the PLNP. A yearling female crossed the park boundary at least 25 times in 16 months.

All 8 bears in the Risnjak area that were marked within the RNP were leaving outside the park up to $25.6 \mathrm{~km}$ (mean $=10.4$ ) (Fig. 3 ). They were located outside the RNP nearly $62 \%$ ( 86 of 139) of the time. However, 4 of 6 dens of bears marked in RNP were inside the park.

The largest area used by an individual bear was $224 \mathrm{~km}^{2}$ in 1,330 days for a 5-year-old male and $147 \mathrm{~km}^{2}$ in 840 days for a 3-year-old female. Sizes of areas used by individuals steadily increased as the number of locations increased, although the rate of increase lessened after about 40 locations for female bears (Fig. 4).

The average annual range of 4 male bears was $128 \mathrm{~km}^{2}$ and $58 \mathrm{~km}^{2}$ for 5 females $(p<0.05, t=2.87, \mathrm{df}=7)$. Male P2 ranged over $153 \mathrm{~km}^{2}$ in the 1 st year of tracking ( $n=38$ locations), $174 \mathrm{~km}^{2}$ in the $2 \mathrm{nd}(n=18)$ and $95 \mathrm{~km}^{2}$ in the 3rd $(n=23)$. The other male, R4, ranged over $89 \mathrm{~km}^{2}$ in one year $(n=15)$. Annual ranges for females were: $84 \mathrm{~km}^{2}$ (P1, $n=89$ locations); $53 \mathrm{~km}^{2}(\mathrm{R} 2, n=27) ; 31$ and $96 \mathrm{~km}^{2}$ in 2 consecutive years (R5, $n=17$ and 14, respectively); and $28 \mathrm{~km}^{2}$ $(\mathrm{R} 9, n=15)$. 


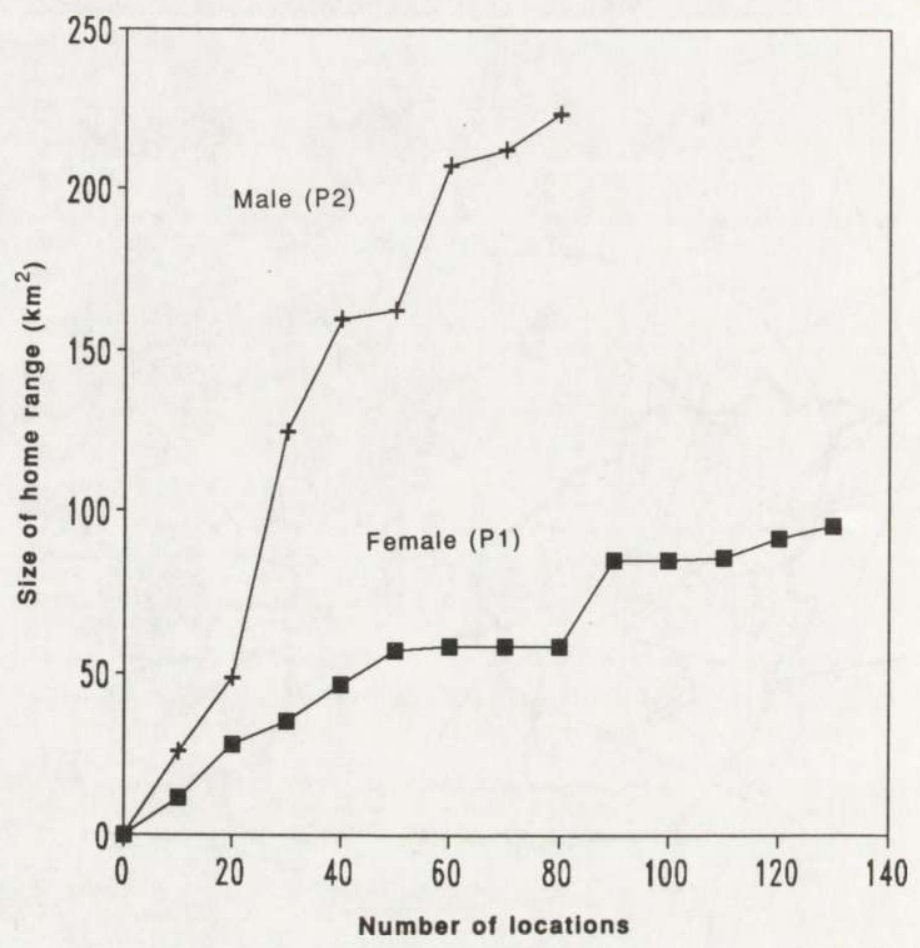

Fig. 4. Cumulative growth of ranges in relation to increasing numbers of locations for two brown bears in Plitvice Lakes National Park, Croatia.

No significant differences were found among spring, summer, and fall range sizes. Average winter range was significantly smaller than other seasonal ranges $\left(p<0.05, t=2.04, \mathrm{df}=35\right.$ ), and averaged $4 \mathrm{~km}^{2}$ (range: $0-18, n=5$ ) compared to $28 \mathrm{~km}^{2}$ (range: $1-102, n=32$ ). Average winter and fall ranges of male vs female bears showed now significant difference. However, spring and summer male ranges were significantly larger than female ranges (spring: $81 \mathrm{vs} 18 \mathrm{~km}^{2}$, $p<0.05, t=3.2, \mathrm{df}=3$; summer: $34 \mathrm{vs} 11 \mathrm{~km}^{2}, p<0.05, t=2.4, \mathrm{df}=13$ ).

A total of 143 straight-line day to day distances were obtained (Fig. 5). The range was 0.2 to $8.5 \mathrm{~km}$ and the median was $1.5 \mathrm{~km}$. Sixty seven percent ( $n=$ $95)$ of the daily movements were less than $2 \mathrm{~km}$ and only $2 \%(n=3)$ were greater than $7 \mathrm{~km}$. Only males moved over $7 \mathrm{~km}$. The difference in daily movements between males and females was not significant $(p>5 \%$, log transformed data).

Marked bears exhibited no obvious territorial behavior. Bears in Plitvice Lakes area shared their known home ranges with 2 to 11 (mean $=7.7$ ) known ranges of other bears. In the Risnjak area all 8 bears marked within RNP had overlapping ranges. 


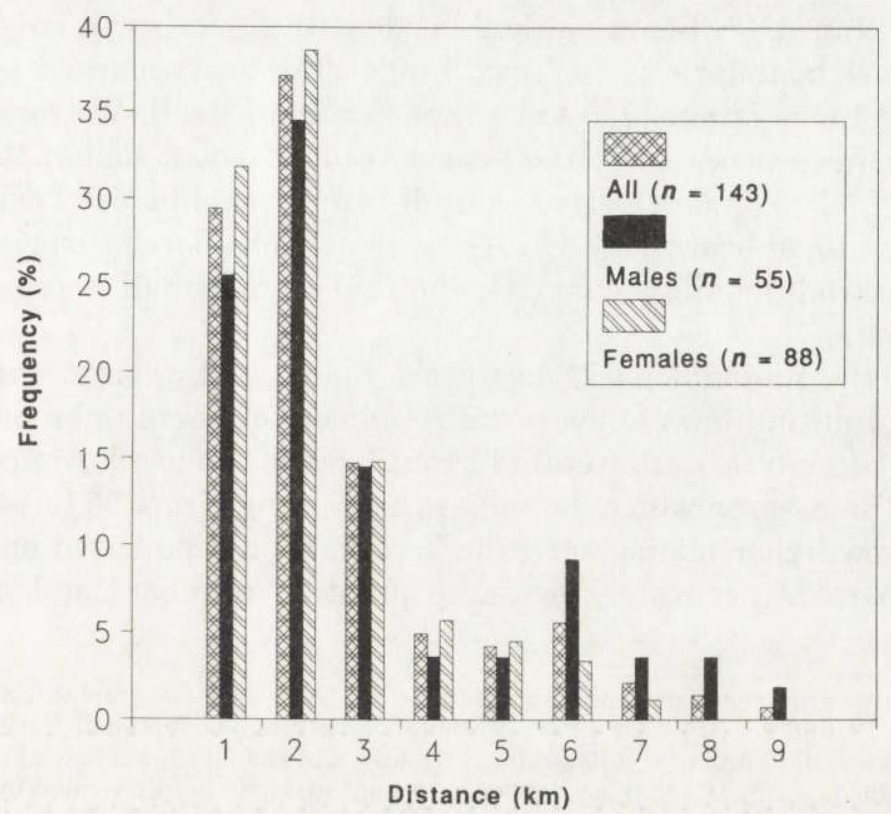

Fig 5. Frequency distribution of straight-line distances between consecutive day locations of brown bears in Croatia.

\section{Discussion}

Individual bear ranges increased in size over time. We found no clear evidence that an asymptote would be reached with increasing numbers of locations. The simple concept of a finite home range seems inapplicable for brown bears which are "wide-ranging creatures of landscapes" (Schoen 1990).

Documented ranges of males were probably underestimated due to the significantly lower success rate of locating male bears. We estimate that male bears range over an area 2 to 5 times larger than females during the same time span. Much larger ranges of male vs female bears were published for European (Bjarvall et al. 1990) and North American brown bears (Craighead 1976, Pearson 1976, Blanchard and Knight 1991).

Distances traveled by males and females were similar, but females confined their movements to a smaller area. Day-to-day movements were similar to those reported for other European brown bears (Roth 1983, Clevenger et al. 1990), but smaller than those reported for North American brown bears (Craighead 1976).

Prior to our study, the managers and local experts of PLNP believed that each mountain ridge within the park supported a distinct bear population. The mean of the longest axes of ranges of 25 bears was $13.7 \mathrm{~km}$, and the longest was 30.2 $\mathrm{km}$. The maximum distance between two points within PLNP is only $23.0 \mathrm{~km}$, 
and $8.4 \mathrm{~km}$ within RNP. Bears marked inside both Parks spent only $48 \%$ of their time within park boundaries. Combined range of all bears marked within Plitvice Lakes was 3.8 times larger $\left(736 \mathrm{~km}^{2}\right)$ than the Park itself. We consider this the minimum size needed to satisfy the yearly needs of about half of the bear population using PLNP. We also believe that all bears travel across Park boundaries.

The movements of bears outside RNP were not considered surprising by locals, and they were traditionally aware that the RNP is too small to provide adequate habitat for bears.

Outside of the national parks bears are managed by forest enterprises and hunter clubs. Hunting laws allow certain numbers of bears to be harvested each year if at least $40 \mathrm{~km}^{2}$ of each hunters' group area is timbered. Areas of 8 hunting clubs in the Risnjak area which do harvest bears range from 55 to $148 \mathrm{~km}^{2}$ (mean $=96 \mathrm{~km}^{2}$ ). Brown bear management in Croatia should be based on much larger land areas to more accurately assess population numbers and the effects of hunting.

Acknowledgements: This research was supported by the National Geographic Society, the Swiss National Science Foundation, Plitvice Lakes National Park, Risnjak National Park, Delnice Forest Enterprise, the Scientific Fund of the Republic of Croatia and the Graduate School of the University of Wisconsin, Madison. We gratefully acknowledge the enthusiastic help provided by students of the Veterinary Faculty in Zagreb during data collection. We also thank the authorities and personal of the Plitvice and Risnjak National Parks for the organizational and technical help. We are most grateful to: A. Frkovic, J. Malnar, F. Salopek and R. Ruff.

\section{References}

Bertovic S. and Martinovic J. 1981. Bioekološke značajke. [In: Gorski kotar. I. Tomac, ed]. Fond knjige “Gorski kotar”, Delnice: 27 - 43. [In Croatian]

Bekoff N. and Mech L. D. 1984. Simulation analyses of space use: Home range estimates, variability, and sample size. Behav. Res. Method. Instrum. Comp. 16: $32-37$.

Bjarvall A., Sandegren F. and Wabakken P. 1990. Large home ranges and possible early sexual maturity in Scandinavian bears. Int. Conf. Bear Res. and Manage. 8: 237 - 241.

Blanchard B. M. and Knight R. R. 1991. Movements of Yellowstone grizzly bears. Biol. Conserv. 58: $41-67$.

Clevenger A. T., Purroy F. J. and Pelton M. R. 1990. Movement and activity patterns of a European brown bear in the Cantabrian Mountains, Spain. Int. Conf. Bear Res. and Manage. 8: 205 - 211.

Craighead F. C. 1976. Grizzly bear ranges and movements as determined by radiotracking. Int. Conf. Bear Res. and Manage. 3: $97-109$.

Huber D. and Morić S. 1989. [Brown bear damage in Yugoslavia]. Proceedings of the third symposium "Savremeni pravci uzgoja divljači". Savez veterinara i veterinarskih tehničara Jugoslavije, Beograd: 197 - 202. [In Croatian]

Huber D. and Roth H. U. 1986. Home ranges and movements of brown bears in Plitvice Lakes National Park, Yugoslavia. Int. Conf. Bear Res. and Manage. 6: 93 - 97.

Makjanic B. 1971/72. [On the climate of the Plitvice Lakes area]. Geografski glasnik 33-34: 5 - 24. [In Croatian]

Mohr C. O. 1947. Table of equivalent populations of North American small mammals. Am. Midl. Nat. 37: $223-249$.

Pearson A. M. 1976. Population characteristics of the arctic mountain grizzly bear. Int. Conf. Bear Res. and Manage. 3: $247-260$. 
Roth H. U. 1978. Zur Verbreitung und Verbreintungsdynamik der letzten autochthonen Braunberen (Ursus arctos) der Alpen, Trentino, Italien. Ph. D. thesis, University of Bern, Bern: $1-101$.

Roth H. U. 1983. Home ranges and movement patterns of European brown bears as revealed by radio-tracking. Acta zool. Fennica 174: $143-144$.

Servheen C. 1990. The status and conservation of the bears of the world. Int. Conf. Bear. Res. and Manage. Monogr. Series No. 2: $1-32$.

Schoen J. W. 1990. Bear habitat management: a review and future perspective. Int. Conf. Bear. Res. and Manage. 8: 143 - 154.

Stoneberg R. P. and Jonkel C. J. 1966. Age determination of black bears by cementum layers. J. Wildl. Manage. 30: $411-414$.

Received 20 May 1992, accepted 8 March 1993. 